\title{
"Kia hiwa rā!" How Māori-language journalists adapt elements of whaikōrero for newswork
}

\begin{abstract}
Aotearoa has a substantial Māori-language news and current affairs sector. A notable aspect of the field is the way in which journalists have imported elements of the ancient and enduring art of whaikōrero, or public oratory, into standard structures of news communication and framing. For example, incantations that are commonly used to open whaikōrero are refashioned to open news shows, and figures of speech based in ancient thought are reinterpreted to illuminate modern concepts. Using textual, intertextual and conversation analysis, this novel paper examines the language of journalists and presenters on four Māori-language news and current affairs programmes to demonstrate how they weave elements of whaikōrero into their on-air work. This paper also discusses the cultural and linguistic issues broadcasters consider.
\end{abstract}

\section{Introduction}

Māori were the first inhabitants of Aotearoa New Zealand, migrating from the northern Pacific Ocean from 1300. They brought with them collectivist values and a highly developed oral culture organised around whakapapa, a word that refers to genealogical descent but also to the belief that all things in the natural and spiritual worlds are related and interdependent (Walter $\&$ Reilly, 2018). In the 1800 s, the country was colonised by 
the British. Despite the British Crown and Māori signing the Treaty of Waitangi in 1840, which promised to protect indigenous assets, culture and language, Crown policies of land alienation and cultural assimilation severely eroded Māori language and culture (R. Walker, 2004). In the 1980s, legal action under the Treaty forced the Government to make concrete steps to protect te reo Māori (the Māori language) and secure Māori access to broadcasting assets (J. Middleton, 2010). This paved the way for state-funded Māori radio and television. The country now has four daily news and current affairs shows in te reo, two on television and two on radio. They are:

- Te Karere, which began in 1983 as a five-minute bulletin on the state broadcaster, Television New Zealand. Now $22 \mathrm{~min} 30 \mathrm{~s}$ long, the bulletin airs on weekday afternoons and is available online.

- $\boldsymbol{T e}$ Ao, which is broadcast seven days a week at $6.30 \mathrm{pm}$ Māori Television, a state-funded broadcaster launched in 2004 and also online; the show is 26 mins. At the time the data for this paper was collected, the news show was named $T e$ Kāea.

- Waatea News, which consists of six-minute bulletins in te reo Māori from $7 \mathrm{am}-6 \mathrm{pm}$ on weekdays. Since 2004, these have been produced by Radio Waatea, a pan-tribal station in Auckland that distributes the bulletins to 21 other stations and archives them as public podcasts.

- Manako, which is a 55-minute Māori-language current affairs show that runs Sunday to Thursday nights on Radio Waatea. It features 10minute interviews with commentators on news of the day in the Māori world which are made available as podcasts.

Māori-language reporting generally follows the structural, technical and story-telling conventions of the 
Anglo-American model, but gazes through a lens informed by Māori language, the Māori world view and indigenous social, economic and cultural preoccupations (A. Middleton, 2020). However, the news services are not funded for news content per se. Rather, they are funded under a national language revitalisation policy to ensure that te reo Māori is part of the 'languagescape', of which news is deemed an important part.

The reality is that te reo Māori is "somewhere between definitely endangered and severely endangered (Te Māngai Pāho, n.d., para. 17); just 10.6\% of Māori speak te reo "well or very well", but many more are learning the language (Statistics New Zealand, 2014a, p. 8). Māori-language reporters are acutely aware that they are role models and agents of language revitalisation, and many of them call on the elements of the ancient art of whaikōrero, or public oratory, which encompasses a wide range of proverbs, metaphors, allusions to ancient stories and references to spiritual concepts (A. Middleton, 2020).

\section{Methodology}

The data in this paper comprises every episode of the four shows, either recorded at the time or downloaded as podcasts, during the period Sunday August 20 to Saturday August 26, 2017, a week chosen for convenience. The texts were transcribed to identify data of interest. Semi-structured, recorded qualitative interviews were also conducted with the shows' journalists and presenters and transcribed. To demonstrate how elements of whaikōrero were woven both purposefully and spontaneously into news communication and framing, textual analysis (Bainbridge, 2008; Fürsich, 2009; McKee, 2003; Richardson, 2007), intertextual analysis (Fairclough, 2003) and conversation analysis (Liddicoat, 2011; Sidnell, 2011) were employed. 


\section{Whaikōrero: An ancient tradition blended into the news}

Te reo has two registers. One is te reo opaki, or the language of everyday communication, with the shortcuts and idioms common to routine social interaction. The second, te reo okawa, or the formal register, includes whaikōrero, or public oratory. Whaikōrero showcase one's eloquence and cultural knowledge (Mahuta, 1974); they may draw on genealogy and history, employ elaborate and sometimes obscure figures of speech, and address the Māori deities through karakia (incantation) (Rewi, 2010).

In centuries past, whaikōrero was the primary way to transmit important information between and within iwi. It was:

The primary medium for expressing opinion and presenting topics for discussion. It helped people make decisions with regard to all matters affecting their living arrangements, their work, and their daily, monthly and yearly activities that would keep them safe. If there were any major issues to put before the people, each speaker would stand and air their opinion until all concerned had expressed what they had to say (Rewi, 2010, p. 14).

Whai means to follow and kōrero to speak, reflecting the expectation that speakers build on each other's commentary (Rewi, 2010) - something like a news story laying out various points of view. In the 21 st century, whaikōrero may no longer be the primary disseminator of news and mediator of power, but it endures. Whaikōrero in sacred spaces is mostly carried out by men and remains an essential feature of most social gatherings, particularly formal and ceremonial events.

\section{The structure of whaikōrero}

Whaikōrero generally follows a three-part structure. In the tau or opening, the speaker indicates that a formal discourse is coming. In the kaupapa, the speaker greets the dead and the living before moving to 
the take, or discussion of the issue at hand. The final portion, the whakamutunga or ending, features a traditional waiata tautoko, or song in support, started by the speaker or his entourage.

The length of individual whaikōrero vary; the speeches that Rewi transcribed in his important book Whaikōrero (2010) ranged from $3 \mathrm{~min} 13 \mathrm{~s}$ to $13 \mathrm{~min} 23$ $\mathrm{s}$. Each section of a whaikōrero can be subdivided further into defined content and speech styles. However, there are variants (Barlow, 1991; Mahuta, 1974; Rewi, 2010), and whaikōrero should not be viewed as one-dimensional (Rewi, 2004). Greetings to the dead, greetings to the living and the topic of discussion are the essential components. The diagram below is based on Mahuta (1974). 


\section{Whaikörero structure, indicating components and options}
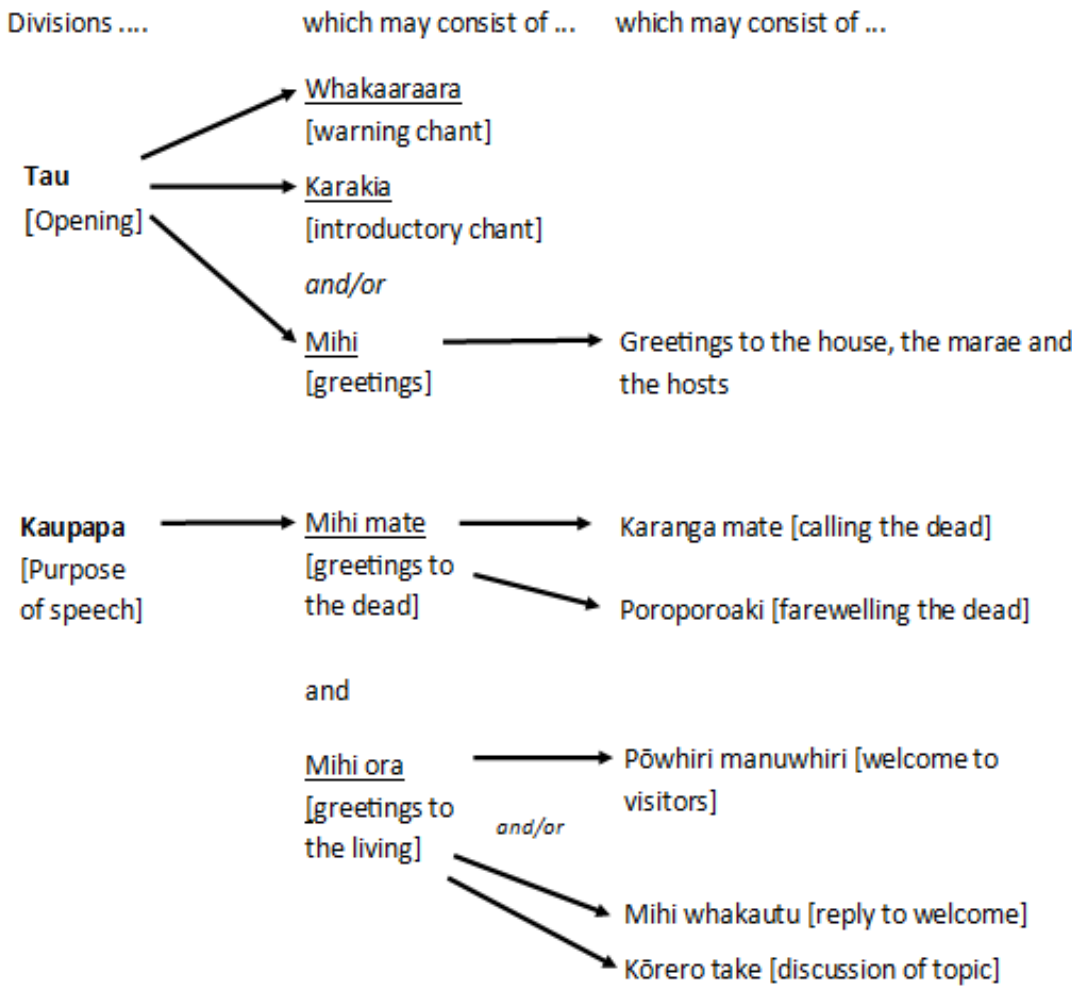

and

Whakamutunga $\longrightarrow$ Waiata tautoko [song in support]

[conclusion] $\longrightarrow$ Kōrero whakamutunga

Based on Ma huta (1974).

Figure 1: The structure of whaikōrero 


\section{Tau: Opening}

\section{Whakaaraara: The call to attention}

The whakaaraara is a short, sharp utterance that Williams (1971) defined as a "chant, to keep the watch awake, or give the alarm in time of war" (p. 14). These chants, handed down through the generations, have become a colourful, evocative way to announce one's attention to speak (Hiroa, 1949; Rewi, 2010). Commonly heard today is the ancient phrase "Kia hiwa rā!". Hiroa (1949) recorded it as below:

Kia hiwa ra e tenei tuku

Kia hiwa ra e tera tuku

Kei apurua koe ki te toto.

O hither terrace, be on the alert

$O$ yonder terrace, be on the alert

Lest ye be smothered in blood (p. 389).

A whakaaraara in the context of oratory often ends with the phrase "Tihei mauri ora!", which means "the sneeze of life" and serves to say, "here I am "let there be life" or "I speak" (Kāretu, 1992). The phrase refers to the origins of humans; the god Tāne breathed life into the first woman, who sneezed (Rerekura, 2007; Rewi, 2010; Salmond, 2004). A speaker uttering these words, said Rewi (2010), "is establishing this particular setting as tapu, imbedding it with all the sanctity, formality, spiritualty and revere of the Māori world" (p. 152).

Te Karere, Te Kãea and Manako regularly used whakaaraara to open. Short and crisply delivered, they were clearly a call to attention. On Manako, host Tumamao Harawira intoned a version of the above whakaaraara:

Kia hiwa rā, kia hiwa rā!

Kia hiwa rā ki tēnei tuku, kia hiwa rā ki tērā tuku.

Kia tū, kia aho, kia mataara! 
Be alert, be alert!

Be alert on this terrace, be alert on that terrace.

Stand up, be awake, be wary!

He then added:

Tīhei mauri ora.

Let there be life/I speak (August 20, 21 and 23, 2017).

Harawira said that it was natural for him to structure his radio openings as if he were about to deliver a real whaikōrero. In news, as on the marae, the whakaaraara was important to "grab the listener's ear".

Manako and Waatea News are monolingual shows, but Te Karere and Te Käea are subtitled in English, and this is the point at which we need to briefly explore subtitles and what is translated in them. Translations of Māori concepts into English seem stilted due to the gulf between the worldviews that each language encodes; this is why Te Käea and Te Karere don't translate phrases that are esoteric or rooted in tikanga, such as whakaaraara. Expanding on this, Te Karere executive producer Arana Taumata said:

In my opinion, what sounds fine, beautiful and natural in te reo Māori can be kind of cheesy and floury when translated into English. We try and protect our language by avoiding literal translations, but default to a generic translation.

In addition, subtitles designed to be read at a glance are not the place to explain cultural concepts. As Taumata explained, "the captioners' usual brief is to provide a summary, a synopsis of what's being expressed, not a word-for-word translation, as there is not enough time to do that".

Te Kãea opened with whakaaraara six nights out of seven. The call "Kia hiwa!" was used twice, the phrase "Kia mataara" three times and "E tūtakarerewa mai" once. All call on hearers to be alert; all were translated as 
"welcome" or "greetings". Te Kāea host Piripi Taylor said that presenters usually scripted their own greetings and links, and had some autonomy:

Kei tēnā kai-whakapaoho, kei tēnā kai-whakataki tōna ake mana me āna ake whakaritenga. Ko tāku, he ù ki ngā tikanga Māori e mōhio nei au, ka nanaiore kia mahia, kia hāpaingia i roto i aku mahi pāpāho, i runga hoki i te arohanui ki taku Māoritanga, otirā ki te reo Māori.

[Each broadcaster and presenter has a certain amount of freedom to do things his/her way. For me, it's about adhering to the tikanga Māori that I know to actively encourage and support its use in my broadcasting duties, all of which stem from a deep affection for my Māori culture and the Māori language as well].

Te Karere usually opens with the lines "Kia ora e te iwi. E haere ake nei i Te Karere". This translates as "Greetings to all; coming up on Te Karere" and is subtitled "Coming up on Te Karere". The assumption is that monolingual viewers will know what "kia ora" means, as it is part of New Zealand English (Deverson \& Kennedy, 2005).

\section{Karakia}

Karakia can be interpreted as prayers, incantations, spells, charms, offertories, ritual words, rites, pleas, invocations and recitations. In daily life, they invoke spiritual guidance and protection from gods and/or ancestors, and are an important element in safeguarding spiritual and bodily health. In ritual, they "are a means of participation, of becoming one, with the atua and the ancestors and with events of the past in the eternal present of ritual" (Shirres, 1997, p. 66).

A tauparapara is a formulaic type of karakia to open a whaikōrero, and can be used as well as, or instead of, the call to attention. Tauparapara are composed for a variety of outcomes, from chants to help move a canoe across land to chants that assist in learning genealogy 
(Rewi, 2010); they also invoke the tapu of whaikōrero (Barlow, 1991; Kāretu, 1992; Rewi, 2010; Salmond, 2004).

Eruera Lee-Morgan was the host of Manako on two nights in the survey week. The show was, he said:

The contemporary marae ... which is formal; te reo okawa and the formalities of a marae still apply ... Marae have traditionally been our means to communicate messages, formally, and it has a formal language ... and rituals that go with it.

He incorporated as much ritual as he felt the format allowed, choosing words that were appropriate for the interviews to come. One night, he chanted a portion of a well-known tauparapara:

Ko te hōkai nuku, ko te hōkai rangi, ko te hōkai nā tō tupuna a Tāne-nui-a-rangi puta ai ko te ira tangata, ki te whaiao, ki te ao mārama. Tihei wā mauri ora.

[I retrace the sacred footsteps that journeyed about the earth and journeyed about the heavens; the journey of Tāne-nui-ā-rangi, from which came human life and the world of light. There was life/I speak]. (Manako, August 22, 2017).

This refers to the journey of the god Tāne to the heavens in search of knowledge and te ira tangata [the human aspect]. Tāne reached his goal, and on his return, created the first woman (Marsden, 2003; Reed \& Calman, 2004; Rerekura, 2007). Below is the incantation as it is usually heard, with the portions Lee-Morgan used underlined: 


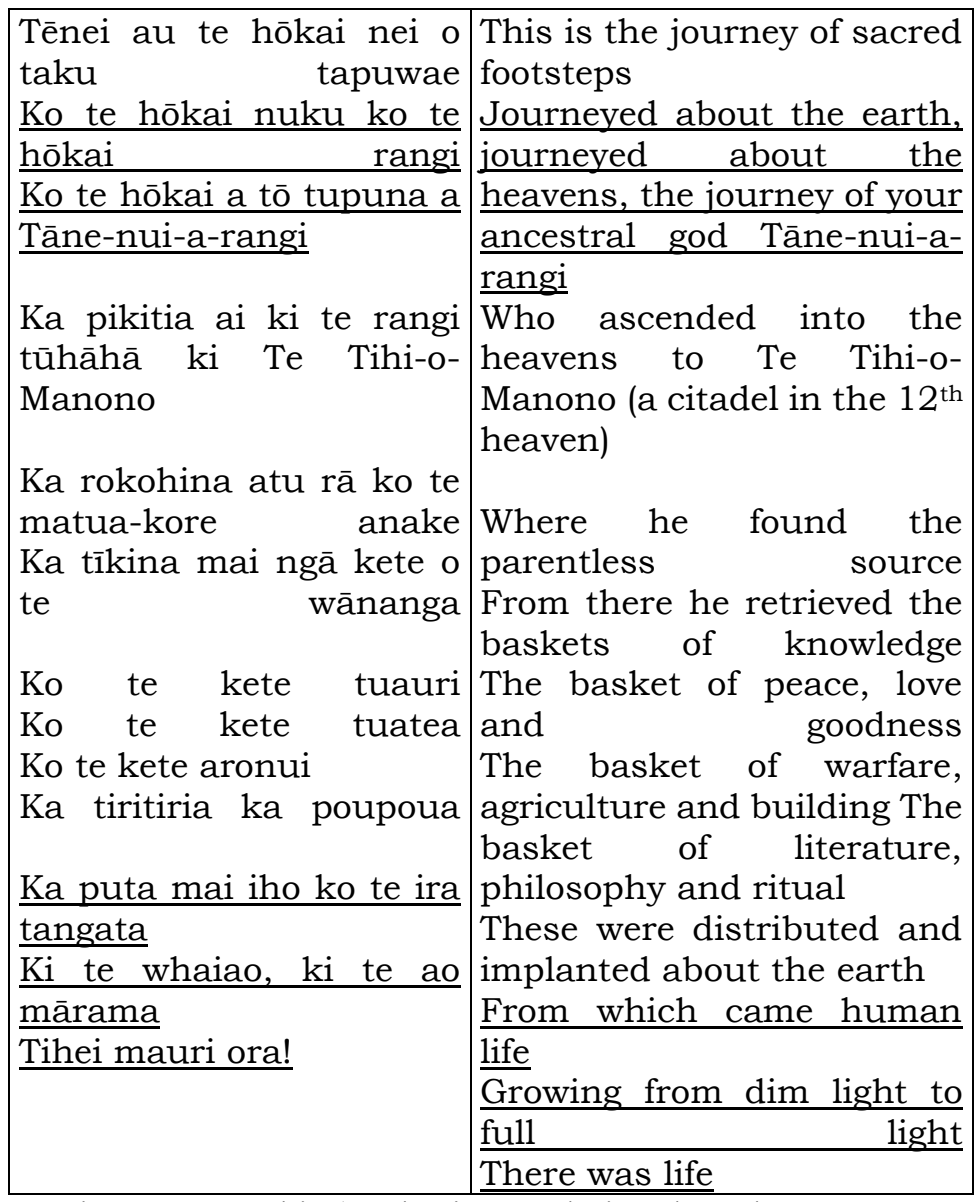

Figure 2: Karakia (Author's translation, based on Kāretu (2008) and Taonui (2006))

The whole incantation takes at least $30 \mathrm{~s}$ and the shortened version $13 \mathrm{~s}$. The full version is well known and, even when shortened, casts one's mind to the spiritual realm.

Te Kãea also made use of portions of tauparapara, but less frequently than the shows discussed earlier. On one occasion, host Piripi Taylor opened the programme 
with "Ko Te Käea tēnei e ōi atu nei," which translates in this context as "This is Te Kāea calling to you". It is a modification of a phrase that appears in some tauparapara, usually as "oioi te pō, oioi te ao", which translates as "the world of the dead and the world of the living cry out". His words were translated as "Welcome to Te Kāea".

As stated above, the rituals of whaikōrero in a formal marae setting invoke the gods and ancestors and create tapu spaces. To invoke tapu necessitates its later neutralisation by the return of participants to a state of noa, or the everyday (Mead, 2003). We need to explore, then, what happens when ancient, sacred speech such as karakia are taken out of the rituals of encounter and used in another setting, such as a radio or television broadcast. Is tapu invoked by the use of karakia, and does that mean whakanoa, or a neutralisation, is required? The place of sacred speech in Māori news media hasn't been overtly addressed by those working in the field. The answer lies in the multiplicity of ways Māori live in the $21^{\text {st }}$ century and the flexibility of tikanga to adapt, and this is addressed in the discussion section.

\section{Mihi: Greetings}

Mihi means to greet or acknowledge, and these greetings often extol "the virtues of the opposite party" (Rewi, 2010, p. 144). Mihi are a core component of any formal exchange, and depending on context, may also be made to the primal parents Ranginui and Papatūānuku; the Christian God; the monarch of the Māori King Movement, the Kingitanga; the marae hosting the event; and its whare nui [meeting house], as the latter often represents an ancestor (Rewi, 2010). Subjects of mihi are usually addressed in the second person.

Numerous examples of mihi to people are provided in Rewi (2010). Among phrases commonly used are:

Nau mai, haere mai!

[Welcome, welcome!] (p. 189); and 
Tēnā koutou, tēnā koutou, tēnā koutou katoa.

[Once, twice, thrice, I acknowledge you all] (p. 202).

In Māori news, opening mihi to the audience often framed them as honoured guests. The speaker might take a straightforward approach, as here:

Tēnā koutou katoa e ngā iwi o Aotearoa. Nau mai, whakatau mai ki ngā pitopito o te wā. [I greet you all, the tribes of Aotearoa. Welcome to the news]. (Waatea News, August 25, 2017, 1pm).

They may use a metaphor or simile that positively compares the audience to people of standing:

E rau rangatira mā huri noa, tēnā koutou katoa (Subtitled as Good evening). [To you, the many chiefs throughout the country, greetings] (Te Kãea, August 23, 2017).

E ngā ihorei tītī e ngā ihorei tātā, tēnā koutou katoa (Subtitled Tēnā koutou katoa and welcome to Te Karere). [Chiefs from near and far, I greet you] (Te Karere, August 21, 2017).

Mihi often favourably compare people to elements of the natural world, such as rivers, birds and trees (Orbell, 1985). Such comparisons are termed kupu whakarite; the English approximation is metaphor (Metge $\&$ Jones, 1995). On Manako, Eruera Lee-Morgan used the flow of tributaries into bigger bodies of water as a metaphor for people coming together to share ideas. He said:

Tēnā rā koutou kei ngā tai e whā o te motu, ā, kua whakawhāiti mai ki te pūtahitanga o te kōrero, ki te kōmititanga mō ngā whakaaro

[I acknowledge the four tides of the country that have gathered together at the confluence of discussion, at the 
convergence of ideas] ... (August 24, 2017). (Radio Waatea, 2017a).

Listeners were also likened to a type of precious greenstone, the semi-transparent whatu tongarerewa. This is a Waatea News presenter opening a bulletin:

Kei ngā whatu tongarerewa o te ao reo Māori, tēnā koutou katoa.

[The greenstone treasures of the reo-speaking world, I greet you all] (August 25, 5pm).

With just $10.6 \%$ of Māori able to speak te reo Māori for everyday purposes (Statistics New Zealand, 2014b), these listeners are undeniably precious resources for revitalisation.

In the sample week, Te Karere greeted viewers with "E aku huia kaimanawa, tēnā koutou katoa", which translates as "my huia birds that consume my heart, I acknowledge you", subtitled as "Tēnā koutou katoa and welcome to Te Karere". The huia, now extinct, had tail feathers that were prized as headwear denoting rank (Orbell, 1985). Here, viewers were again ennobled. Such language, said Te Karere executive producer Arana Taumata, added "daily variety to the show. If we used a standard 'kia ora' at the beginning of each show, it would very quickly become a bland greeting". There are many and varied metaphors to call on, which "shows the richness of te reo Māori and is a neat and dynamic way of engaging with the viewer".

In the sample week, mountains featured in four of the seven mihi to Te Kãea viewers. Mountains feature heavily in Māori imagery, their physical presence inspiring a range of emotions. Most tribes have a maunga tapu, or sacred mountain (Orbell, 1985) that forms a pillar of individual and collective identity alongside a local body of water and that tribe's ancestral canoe (Orbell, 1985; W. Walker, 2014). In formal settings, people introduce themselves by these landmarks, starting with one's mountain. 
Presenter Piripi Taylor often invoked mountains as, he said, they had mana. The translations below cannot do the sentiments justice, but the attitude they convey is one of respect for the tribes of the land, here metaphorically identified as mountains:

Kei ngā maunga whakamana, tēnā koutou katoa (Subtitle: Good evening). [Prestigious mountains, I greet you] (August 24, 2017).

E ngā maunga whakahī huri noa, rarau mai rā. (Subtitle: Good evening). [Proud mountains of this land, welcome] (August 25, 2017).

Kei ngā maunga kōrero huri noa, tēnā rā koutou katoa (Subtitle:

Welcome). [Speaking mountains of the land, I greet you] (August 26, 2017).

\section{Mihi mate, mihi ora: Farewells to the dead, greetings to the living}

In Mãori thought, the world of the dead exists physically and symbolically. During formal speeches, both hosts and guests summon their dead and farewell them: "Thus, the association of visitor and host at the physical level is paralleled at the spiritual level" (Mahuta, 1974, p. 34). Formulaic phrases to address the dead include:

Haere, haere, haere.

[Farewell, farewell, farewell] (Brooke-White, 1981, p. 28;

Rerekura, 2008, p. 19; Rewi, 2010, p. 193).

Haere ki Hawaiki-nui, ki Hawaiki-roa, ki Hawaiki pāmaomao, ki te Hono-i-Wairua. [Go to the great, long, distant Hawaiki, the meeting place of the spirits] (Mahuta, 1974, p. 35).

Hawaiki is the homeland from which the ancestors migrated, believed to be in East Polynesia (Anderson, Binney and Harris, 2014). 
To summon the dead requires an explicit return to life with a mihi ora, or acknowledgement of the living, in order to separate the two domains. In whaikōrero, the below is a common pairing:

Ka āpiti hono, tātai hono, te hunga mate ki te hunga mate,

[The lines are joined, allow the dead to rest with the dead]

Ka āpiti hono, tātai hono, te hunga ora ki te hunga ora. [The lines are joined, allow the living to remain with the living]

(Brooke-White, 1981, p. 16; Mahuta, 1975, p. 35; Rewi, 2004, p. 184).

The phrase "āpiti hono, tātai hono", or "the lines are joined" comes from a weaving chant. Here, it is used to mean that:

All of the rites of the ancestors are brought out because of the final stitch by death. Just as the weaving and stitching of thread bring together a cloth in which each thread and stitch is part of the whole, so the living and the dead are together part of a whole that is the tribe (Brooke-White, 1981, pp. 21-22).

The tikanga of acknowledging the dead and returning the focus to the living is reflected in Māori news in several ways, generally with a truncated version of the formulae heard in whaikōrero. In this example from an opening of Manako, host Eruera Lee-Morgan acknowledged the grief of the living, then described the journey of the dead to the spirit world before offering a farewell:

Tēnā hoki koutou e tangi mai nā i ō tātou tini aituā kua whai rā i te tira haere o Maruiwi kua heke ki Te Reinga ki te nia i te matoru o te pō. Haere, takoto, okioki.

[I acknowledge all of you mourning our deceased who have followed Maruiwi [an ancient tribe] to Cape Reinga 
[the Northland cape where spirits leap to the underworld] to pierce the darkness of the night]. Farewell, lay in peace, rest in solitude (August 22, 2017).

He then separated the dead and the living, using three kupu whakarite in a row - all of them symbols of vigorous life - to return listeners' thoughts to the living world:

Tēnā koutou kei ngā kākā waha nui, kei ngā tōtara haemata, kei ngā manu honenga o te pae ...

[I acknowledge you, the animated voices of the kākā birds, the vigorous totara trees, the melodious songbirds of the altarl (Manako, August 22, 2017).

A tōtara is a sturdy hardwood tree often referred to as a rākau rangatira, or chiefly tree (Orbell, 1985), and appears frequently in oratory; we discuss its use as metaphor shortly.

On another occasion, Lee-Morgan invoked the dead and the living through the atua of each realm: Hinenui-te-pō, the goddess of death, and Tāne (see Figure 2).

Whakatau hā ō tātou tini aituā ki a Hine-nui-te-pō, whakatau hā tātou ko te hunga ora ki a Tāne-te-waiora.

[Welcome our numerous deceased dwelling in the realm of the goddess of death, Hine-nui-te-pō. Welcome us, the living, in the realm of Tāne-te-waioral (Manako, August 24, 2017).

In the week of the survey, there was a notable death, that of former All Black rugby star and farmer Sir Colin Meads. Known as Pinetree for his stature, Meads, who was Pākehā, died of cancer on Sunday, August 20, 2017, aged 81 . He was revered by Māori and Pākehā alike for his rugby prowess and charitable work and had two funerals: the first at a marae in his hometown of Te Küiti, and the second at a local events centre.

Te Kãea, Te Karere, Waatea News and Manako all covered Meads' death. The reporters involved said while 
there were no rules or prohibitions about the language they used in reporting death, they felt that it was important to adhere to cultural norms around separating the living and the dead. Manako presenter Tumamao Harawira believed that this was particularly important for Manako listeners, many of whom were older, adhered strongly to tikanga and expected demarcation.

To further explore further how linguistic norms around mihi mate and mihi ora are reproduced on air, we turn first to Te Karere. After the reporter's story ended, presenter Rapaera Tawhai maintained separation by spontaneously saying, "Nā, hoki mai ki te hunga ora. Ki ngā take tōrangapū ..." which means "Now, we return to the living. To politics ..." He inserted the line "just used to make sure there was a transition between a story about the dead and then a story about the living ... it wasn't scripted - it just felt right to say it".

A later Te Karere bulletin ran a story about Meads' tangi at the marae. After the report ended, presenter Irena Smith addressed Meads directly with "Moe mai rā, e te tōtara haemata", or "Sleep well, strong-growing tōtara." Her words were not subtitled. About the mihi, Smith said:

That wasn't scripted or written on the autocue to say, but I said it off-the-cuff as a sign of respect and mihi to someone who was widely respected ... it's personally from me, as the presenter; it's my personal acknowledgement to Sir Colin Meads.

She chose the tōtara-tree metaphor "because it suited the man - he was a big man who did big things". Smith was conscious of audience expectations; the mihi served "to finalise a story about a death before moving onto a story about the living". That was important, she said, "as it's part of our tikanga".

Te Karere principal presenter Scotty Morrison is also the show's language and tikanga adviser and said that presenters had discretion on the linguistic devices they employed. One's individual sense of what is 
appropriate at a particular time and place drove decisionmaking: "You'll have presenters who will adhere more to tikanga than others, be more conscious of tikanga than others."

Waatea News didn't use any formal mihi mate in its news bulletins; it has the greatest time pressure of the shows discussed here. However, like Te Käea, Waatea News used various metaphors in talking about Meads. Given his stature and nickname, it was no surprise that the metaphor journalists reached for was the tōtara tree. Here are two examples from Waatea News:

He tōtara nui kua hinga i te wao nui a Tāne, $\bar{a}$, ko te ihorei $\mathrm{i}$ te ao whutupōro, a Colin Meads.

[A great tōtara has fallen in Tāne's great forest - Colin Meads, a star in the rugby world] or, less literally, A figurehead has died - rugby star Colin Meads (August 21, 2017, 3pm).

In this next example, the phrase has been adapted, but its origin is clear:

Tēnā koutou e ngā iwi o te motu. Ko Eru Morgan tēnei me ngā rangona kōrero a Waatea. E mahuta ake nei, kua hinga tētehi o ngā tōtara haemata o te ao whutupāoro.

[Greetings, tribes of the country. This is Eru Morgan with the Waatea news bulletin. Coming up, one of the totara of the world of rugby has passed away] or, less literally, one of the stars of the football world has died (August 21, 9am).

In a Waatea News story later that week, presenter Tumamao Harawira used two metaphors to discuss Meads. He compared him to a kōtuku, or white heron, whose scarcity gave rise to the phrase "He kōtuku rerenga tahi" or "A white heron of a single flight" - meaning a person who is one of a kind, or a talent rarely seen (Orbell, 1985). Harawira also invoked the prized kotuku feathers, or piki kōtuku: 
He kōtuku rerenga tahi a Tā Colin Meads i ōna rā. Koirā tā Wairangi Kopu whai muri mai i te hinganga o tēnei ō ngā tino piki kōtuku i roto o Aotearoa (August 23, 2017, $1 \mathrm{pm})$.

[Sir Colin Meads was one of a kind in his time. That's according to Wairangi Kopu, following the death of one of New Zealand's greatest treasures].

As death often prompts orators to be highly eloquent (Rewi, 2010), so Harawira used expressive language to report notable deaths: "Poetical ... as opposed to just the normal, everyday language that you use in news bulletins".

\section{Interviewees addressing the dead}

It's not unusual for Manako interviewees to deliver a farewell direct to a deceased. On the day Colin Meads died, Manako host Tumamao Harawira and Henare Kingi, a radio broadcaster now in his 80 s, discussed the sportsman's life. At the end of their conversation, Harawira prompted Kingi to share his memories of Meads with these words:

Hei whakakapi ake i tā tāua kōrero, e te matua, kia kōrero poto tāua mō te hinganga o Colin Meads i te rā tonu nei. Kia mōteatea tonu te ngākau.

[To round off our chat, uncle, let's talk briefly about the death of Colin Meads today. Our hearts are grieving] (August 20, 2016).

Henare Kingi shared his memories of Meads for a few minutes, then segued into a poroporoaki or farewell address:

E kara, e Colin, haere rā. Ko koe tēnei kua mahue mai te ao hou nei i a koe. Ka hoki atu koe ki tōu nei kaihanga. Nā reira, haere, e kara, haere, haere, haere. 
[Dear friend, Colin, farewell. You have left this world. You are returning to your creator. So, my friend, farewell, farewell, farewell].

\section{Körero take: The main topic and the place of proverbs}

The kōrero take is the section where the "news" is dispensed and opinions aired. Speakers can approach their topic in many stylistic ways, perhaps calling on proverbs, songs or haka (Metge \& Jones, 1995; Moorfield \& Johnston, 2004).

Many Anglophones (and, in my experience, many English-language journalists) equate proverbs with wornout, hackneyed phrases that people "dismiss ... rather cavalierly as clichés of not great depth or literary merit" (Metge \& Jones, 1995, p.3). However, Māori speakers don't share this view, nor Māori journalists. In a society where the stories and lessons of the past are venerated, ancestral sayings carry weight (Firth, 1926; R. Walker, 1978).

These sayings are called whakataukī; they are "short, highly informative, expressive and memorable" (McRae, 2017, p. 66) and in an oral society, are "a vital way of memorising and transmitting knowledge" (p. 65). Apparent simplicity hides great depth, as Metge and Jones (1995) wrote:

While they often appear to be simply recording observations about nature, they are in fact talking about human beings and their interactions. They operate through analogy ... for this purpose, they call on a rich repertoire of metaphors which evoke vivid mental images and lend themselves to visual expression. A large number of these metaphors are drawn from the world of nature, but they also include the things humans make (ropes, cloaks, houses, canoes) (p. 5).

Whakataukī also link past and present, particularly timeless quotes about human nature and endeavour. In addition, as Metge and Jones (1995) noted, whakataukī "sound good. They are characterised by 
musical cadences, pronounced rhythms, and the contrast of flowing with staccato phrases. They make much use of repetition, opposition and balance. They exploit the possibilities of onomatopoeia" (p. 5).

Figures of speech are useful shortcuts for journalists. To Radio Waatea's Eruera Lee-Morgan, they are "scene-setters ... one little metaphor can tell the whole story, especially if you know the context". For example, he wrote a story about a general election special that Māori Television was preparing. Wanting to express the Māori equivalent of "many hands make light work," he alluded to this well-known saying:

Mā whero, mā pango, ka oti ai te mahi By red and black the work is finished (Mead \& Grove, 2003, p. 292).

Red refers to kōkōwai, a mixture of shark oil and red ochre that was smeared on the body of a chief. Rankand-file manual workers looked black by comparison (Parker, 1966). Lee-Morgan recontextualised the saying to say that the broadcast's success would depend on many people from all levels of the organisation working as one. The phrase "by red and black the work will be completed" became "by red and black, the live broadcast will succeed".

E takatū ana a Whakaata Māori ki te whakahaere hōtaka motuhake e pā ana ki te Kōwhiringa Pōti ā-Motu. Hei tā Oriini Kaipara, kaiwhakataki o te hōtaka, mā whero, mā pango e tutuki ai te whakapāohotanga arorangi nei.

[Māori Television is preparing itself to produce a special broadcast for the night of the General Election. According to presenter Oriini Kaipara, with everyone pitching in, the live broadcast will go well].

In whaikōrero, orators exploit the fact that whakatauki are not fixed: "The art of using whakatauki involves applying them in new contexts" (Metge \& Jones, 
1995, p. 6). On Waatea News, Tumamao Harawira opened a story about the opening of Māori Television's new headquarters by refreshing a whakatauki first recorded in writing in 1857 :

Ka mate kāinga tahi, ka ora kāinga rua. One dwelling is overrun, but the second is secure (Mead $\&$ Grove, 2003, p. 169).

The various interpretations all boil down to having two ways to achieve something. In earlier times, one interpretation was the need to have two plantations in case one failed, and another the necessity for a second dwelling-place that could serve as refuge. The English equivalent is "having two strings to your bow" (Mead \& Grove, 2003).

In this case, the lease on Māori Television's expensive inner-Auckland building was expiring, and the company's leaders wanted to move to a more costeffective home (Haunui-Thompson, 2015). This was the full opening of the news story:

Ka mate kāinga tahi, ka ora kāinga rua. He rangi nui āpōpō ka tū mō ngā kaihāpai o te kaupapa o Whakaata Māori. Āpōpō whakatuwheratia ai te whare hou o Whakaata Māori ki Tāmaki ki te Tonga.

[Their first home has outlived its usefulness, but another home is ready. It's a big day tomorrow for the staff of Māori Television - their new home in south Auckland will be opened] (Waatea News, August 23, 2017).

In journalistic terms, the whakatauki was used as a drop or delayed intro - the key point was not plainly stated in the first sentence, coming in the second (Henshall \& Ingram, 2012). While Harawira acknowledged that using a saying as a drop intro didn't get listeners straight to the point, the revitalisation funding model underpinning Māori-language news influenced how he spoke: 
The news bulletin is about the language just as much, if not more, than the actual story. So it's about having that real eloquent style about writing the language ... the things that our eloquent speakers use.

A Waatea News story about an election candidate opened with a saying that advised preparing soil well in order for subsequent plantings to flourish. The story, by Eruera Lee-Morgan, said:

Mā te ngakingaki $\bar{a}$ mua, ka tōtō $\bar{a}$ muri. Koinei te whakahau a Nanaia Mahuta, mema Māori mō te tūru o Hauraki-Waikato. Hei tā Nanaia mā te whakatakoto tika i te tūāpapa o te Rōpū Reipa, e pai ai ngā mahi ā muri nei.

Cultivate the ground first, and your plantings will flourish later. That's the assertion of Nanaia Mahuta, Māori MP for the Hauraki-Waikato seat. According to Nanaia, if Labour lays a good foundation, it will win the election]. (Waatea News, August 22, 2017).

Having delivered the proverb as a drop intro, he clarified its meaning by adding "if Labour lays a good foundation, it will win the election". He added: "You can never assume what your audience knows and what they don't know. So I qualify, or validate it, with that other brief little explanation as well."

\section{Whakamutunga: Conclusion of whaikōrero}

Whaikōrero are followed by a waiata tautoko, a traditional Māori-language song delivered by the speaker and his group to show solidarity and to lift tapu from the speaker (Rewi, 2010). Orators choose one appropriate to the occasion, as songs contain and transmit ideologies, philosophies and viewpoints (Rewi, 2010). The waiata over, a speaker will usually utter a few sentences to signal his conclusion, perhaps as brief as "Tēnā koutou, ka huri", which translates as "I acknowledge you all, I turn/sit" (Mahuta, 1974, p. 37). Although the waiata has 
not transferred into news, Māori current affairs shows have various ways of bidding farewell.

Most of them use "Tēnā koutou katoa". For example, Waatea News usually ends with the presenter identifying himself or herself if that hasn't already occurred, then delivering a short mihi. The latter is most often "Kia ora" or "Tēnā koutou katoa", which can be translated as "thank you" or "I acknowledge you".

Manako presenter Eruera Lee-Morgan doesn't script his farewells, letting the mood of the show lead him. One night, he employed an extended metaphor, describing the night's interviews as the contents of a woven flax basket that was being returned to its peg in the whare nui:

Heoi anō rā, kua pau te wāhi ki ahau, koinei ahau ka whakairi ake te kete kōrero o Manako ki te pātū, ki te pakitara o tō tātou whare kōrero. Mai i te pou irirangi o Waatea, tēnā koutou, tēnā koutou, tēnā tātou katoa.

[Well, I'm out of time, so I'm about to suspend on the wall of our house the basket of conversations until next time. From Radio Waatea, many thanks to you all] (Manako, August 24, 2017).

Lee-Morgan often refers to both Christian and Māori gods in his farewells, although his own worldview is rooted in Māori cosmology. There was a time when he would close Manako according to his own worldview. However, after a complaint that he wasn't recognising "the whole wairua tapu", or range of sacred and spiritual beliefs, he started including an acknowledgement of Christianity. Covering the spectrum, Lee-Morgan said, required "a strategic choice of words". This was one of his farewells in the sample week:

Heoi anō kua pau te wāhi ki a tātou o Manako mō tēnei pō, heoi anō rā kia tau ngā manaakitanga o te runga rawa, te wāhi ngaro ki runga i a koutou katoa. Noho ora mai. 
[Well, that's it - my time's up for another evening. May the care of God and those who have gone beyond be bestowed upon you all. Stay well] (Manako, August 22, 2017).

In Māori thought, te wāhi ngaro means, depending on context, the hidden realm, the world of gods and spirits, divine intervention and the heavens (Moorfield, n.d.). In the survey week, Te Käea six days out of seven invoked the wāhi ngaro:

Ngā manaakitanga o te wāhi ngaro ki te tī, ki te tā, tēnā rā koutou katoa. (Subtitled as Thanks for joining us, good evening).

[May one and all enjoy the care of those in the hidden realm]. (Piripi Taylor on Te Kãea, August 24, 2017).

The Christian God, or te runga rawa, was invoked once:

Ngā manaakitanga o te runga rawa ki te tī, ki te tā, tēnā rā koutou katoa.

[The care of God over everyone. I acknowledge you all] (Subtitled as thanks for joining us, good evening). (Piripi Taylor on Te Kãea, August 25, 2017).

Te Karere used a variety of sign-offs in the survey week. One was a simple "Kia ora tātou katoa", subtitled as such. Another was "Kia tau te manaakitanga o te wāhi ngaro ki a koutou katoa", which was not subtitled; it means "May the care of the hidden realm rest upon you all".

One night, listeners heard a more unusual farewell - a whakatauki that has become a signature $T e$ Karere sign-off and has spread beyond the show. The proverb demonstrates the power of reo-Māori journalism to influence language use. The sign-off had two parts, neither of which were subtitled. The first part was straightforward: 
Kia haumaru te noho ki tō koutou kāinga maha.

[May you all be safe in your many home areas]

However, the second half was distinctly Māori:

Turou parea, turou Hawaiki.

[Let the ancient homeland of Hawaiki glisten in your mind's eye for eternity] (Te Karere, August 22, 2017).

Most Māori and East Polynesian traditions refer to migration from Hawaiki. The mythical homeland features frequently in songs, proverbs and genealogies; the dead are believed to travel back to Hawaiki (Anderson et al., 2014). The meaning of the phrase, said Te Karere presenter Scotty Morrison, was "never forget your origins, where you come from and use that as power for you as you stride into your future". It was, he said, a phrase commonly used by tohunga [priests] on the migratory waka as they left for Aotearoa New Zealand.

However, in the $21^{\text {st }}$ century, this whakatauki is better known in translation as "May the Force be with you" - the phrase that defines the Star Wars movie franchise. The reason reflects not just the ability of highprofile media people like Morrison to shape language use, but their desire to package te reo so that young people embrace it. Morrison said that he came across the phrase "Turou parea, turou Hawaiki" in the papers of a Te Arawa elder.

Later, he went to see his cousin Temuera Morrison playing Jango Fett in the 2002 film Star Wars: Episode II - Attack of the Clones. Listening to the actors say "May the Force be with you" - the Force being a metaphysical energy that connects all things (Moyers, 1999) - he had an idea. The concept of a metaphysical energy is familiar to Māori, so packaging "Let the ancient homeland of Hawaiki glisten in your mind's eye for eternity" as "May the Force be with you" would appeal to young Māori.

Later, when Morrison decided that it would be useful to give Te Karere a signature sign-off, he chose that 
phrase. "Television has ... more reach than anything else, apart from radio," he explained. "If you're using words on a regular basis on television, they start to become normal and people start to use them." That reach has made "Turou Hawaiki" very well known. However, at present, we have no way of assessing whether people know its ancient meaning or have latched on to the modern translation only.

\section{Discussion}

\section{Intertextuality}

The adaptation of elements of oratory into news and current affairs texts, both spoken and written, is intertextuality - the shaping of a text by another text (Fairclough, 2003). In academic terms, texts encompass all forms of human communication, written and oral (Fairclough, 2003; Orr, 2011); from books, newspaper articles, songs and films, to internet memes, oral narratives, prayers and the likes. According to Fairclough (1992):

Intertextuality is basically the property texts have of being full of snatches of other texts, which may be explicitly demarcated or merged in, and which the text may assimilate, contradict, ironically echo, and so forth (p. 84).

Intertextuality and innovation are not unusual in the oral arts of the Māori world - indeed, they are expected. As Dewes (1975) wrote:

New Zealand is very rich in Maori oral arts and a vast storehouse remains in the minds and on the lips of Maori oral artists ... our literary tradition is a creative one because it draws on the indigenous past, and borrows, changes and continues to comment on and adapt to contemporary situations. It is a living tradition extending continuously from the past to the present ... it has a history of persistence, change and innovation (p. 53). 


\section{Ensuring understanding} (2004) noted:

Nothing we say is truly original, as Bazerman

We create our texts out of the sea of former texts that surround us, the sea of language we live in. And we understand the texts of others within that same sea. Sometimes as writers we want to point to where we got those words from and sometimes we don't. Sometimes as readers we consciously recognise where the words and ways of using words come from and at other times the origin just provides an unconsciously sensed undercurrent. And sometimes the words are so mixed and dispersed within the sea, that they can no longer be associated with a particular time, place, group, or writer. Nonetheless, the sea of words always surrounds every text (pp. 83-84).

However, not everyone is swimming equally strongly in the sea of te reo Māori. The ability to interpret what one hears and reads requires skills embedded in linguistic, cultural and social knowledge that is influenced by upbringing, education, life experience and other variables (Fairclough, 1992). Gaps in knowledge may hinder comprehension (Smith \& Higgins, 2013).

Journalists working in te reo have to strike a balance between extending the language used by competent speakers and ensuring the largest possible number understand the message. Looking at subtitled television news, it was clear that content that was symbolic rather than informational was not translated, and into this category fell the Tauparapara, ritual chant and the metaphors used in greetings. They set a certain tone but did not convey new information.

However, care was taken with informational content - that is, news stories themselves - to aid comprehension, and journalists employed various strategies. They used straightforward language in short sentences, mostly structured in the inverted pyramid style common to news stories (Hannis, 2014). If they 
deviated, they took care to take the listener with them as much as was possible in the time available.

Te Karere presenter Scotty Morrison employs two strategies to ensure viewer understanding. One is to introduce unfamiliar words in such a way that the context makes meaning clear. Another tactic is to define the meaning of an unfamiliar word immediately afterwards, prefacing it with "arā" [that is to say].

So I might say 'kei te hanepī ngā whakaaro o te iwi, arā, kei te rangirua ngā whakaaro o te iwi' [people are worried] $\ldots$ and people will understand rangirua [concerned] and then they'll make the connection: 'Oh, that's what hanepi is, it means to be confused'.

On the issue of proverbs and figures of speech, it was clear that journalists and presenters chose sayings that were relatively well-known across the tribes; they were the sorts of sayings taught in reo-Māori education settings from primary school upwards. This restricted repertoire was necessary to ensure the largest number of people understood, said Arana Taumata, executive producer of Te Karere. But he sometimes wished his reporters could employ a broader range:

We've got a language that's so rich and colourful, but here's the rub. As we know, we are trying to save our language, and only a small percentage of our people are lucky enough to be brought up as native speakers ... out of those native speakers, there's probably an even smaller percentage that get that richness and beauty that our tūpuna [ancestors] had 300 or 400 years ago.

The point I am trying to make is that our language is going through a revitalisation process ... so the use of metaphor, idiom and all that sort of stuff is probably not as utilised as much as it could or should be.

\section{Taking karakia to news settings}

In formal ceremonies, once tapu is called forth by karanga and karakia, we exist in that state of tapu until 
it is neutralised by the hongi [nose press], exchange of breath, and shared food, which serve to "decommission participants" (Durie, 2012, p. 78). In these settings, karakia are a powerful way to call the tapu and the mana of our atua and our tūpuna to us; the formulaic nature of karakia ensures that we are speaking as they spoke (Shirres, 1997): "This is a oneness with the living, but also with all those who have gone before them, and a oneness which extends right back into te kore, the 'nothingness' of the beginning of creation" (p. 90). Durie (2011) wrote that such ritual allowed one to "enter safely into atuaspecific domains and activities with an enhanced sense of sensory awareness and preparedness" (p. 78). The power of karakia come from the atua, and their effectiveness depends "on the faith of the people using the chants" (Shirres, 1997, p. 85).

Pre-contact, that faith was strong. Everyone adhered to rituals, processes and protocols, as survival meant maintaining good faith with the atua of the various domains (Durie, 2012, p. 78). According to academic Te Ahukaramū Charles Royal, quoted in Durie (2011), "Māori lived in and around a very tapu culture ... in the past there was a very strong belief that if you infringe a tikanga or a kawa [fixed ritual] that you would face a very strong retribution of some kind" (p. 110-111).

The most important rituals of life, such as death, exhumation, and the lifting of tapu, were overseen by men trained in the priestly arts (Marsden 2003), and their chants were seen to have great power (Hiroa, 1949). However, every person had a stock of karakia for everyday life to help heal wounds, for example, or knit broken limbs; appease Tangaroa, god of the sea, for the first fish caught; and ensure success in hunting and gardening (Shirres, 1997).

We now live in a world, where society - and survival - is no longer predicated on tapu and noa and the mechanisms of social and individual control they fostered. Te Ahukaramū Charles Royal said, "I don't think people are beholden to the tapu system any more ... 
attitudes and ideas about cause and effect have changed". People were no longer "psychologically bound up with certain assumptions, and a common set of understandings ... just isn't there. Our people have widely diverse views of the world and experiences of the world" (quoted in Durie, 2011, p. 111). As Radio Waatea broadcaster Tumamao Harawira observed, "We don't have a real-world experience of what it means to live in a world that is tapu and noa."

Time passes and customs change. As Mead (2012) wrote:

Mātauranga Māori continues to evolve both in the way it is understood and in the range of ways it is applied in today's world. Within the basket of knowledge itself, some ideas are held to be crucial and critical, while other ideas are subject to amendment or better left alone, and there is a wide range of new ideas to select from and to embrace (p. 12).

Among these new ideas is the use of karakia in domains beyond the sacred; these are reflections of tikanga as "spontaneous and organic" growing from our "earthly reality" (Durie, 2011, pp. 114-115). Karakia, with their focus on creation, the gods and the forces that brought out tupuna to Aotearoa New Zealand, are not just calls to higher powers, but stories of who we are and how we think, making them powerful statements of identity.

For example, contemporary Māori musicians combine the power of music and the eloquence of old karakia in their work, or compose new ones. ${ }^{1}$ Many tribal reports, while written largely in English, open with a karakia, as do books and academic theses written by Māori. Recordings of karakia are on the internet so people can learn them. As academic Amster Reedy said:

${ }^{1}$ Among them are Tiki Taane, Maisey Rika and Moana Maniapoto. 
The point about karakia and kawa is not how far back you can go but how far forward you can take it. We should not put ourselves in the position of living in the past, but should see that our culture is very relevant to the world that our children and grandchildren will live in (in Durie, 2011, p. 129).

People may no longer live strictly by tapu and noa, but to hear the distinctive cadence and words of a karakia in a news setting or in music ensures that the link to the past is not forgotten; karakia have the power to focus our minds on the primacy of whakapapa, the spiritual realm and the mana of te reo Māori.

However, reworking tikanga raises caveats. In adapting Māori practices for new contexts, wrote Durie (2012), a "theoretical and philosophical base that is derived from mātauranga Māori" must be maintained, and this required "a type of leadership that can mediate between yesterday and tomorrow" (p. 85). The public nature of the journalist's work means that there is great incentive for the best possible exponents of te reo and tikanga to be chosen for on-air work. To use something inauthentically risks an immediate and embarrassing correction by your own community (Mead, 2003).

Māori journalists took different approaches with karakia according to their backgrounds and understandings. Te Karere presenter Scotty Morrison performs ancient karakia for a wide variety of purposes, just as the ancestors did, to help heal illness or remove psychological harm wrought by others. In his media work, Morrison does not use ancient incantations "to protect the integrity and sanctity of those karakia". In contrast, Manako host Tumamao Harawira will recite ancient karakia on radio, but only when he has time to recite them in full; this is to maintain "the integrity of the karakia." Below is one he often uses to open Manako, which evokes Māori migration to Aotearoa New Zealand:

Whakatau hā, whakatau hā

Whakatau hā te rangi e tu iho nei 
Whakatau hā te papa e takoto nei

Whakatau hā te mātuku mai i Rarotonga

Ko ia i rukuhia manawa pou roto

Ko ia i rukuhia manawa pou waho

Whakatina kia tina, te more i Hawaiki

Haumi e, hui e, taiki e (Manako, March 20, 2017).

The chant's age and obscure language makes an accurate translation difficult, and the reader is directed to Orbell and McLean (2002, pp. 49-51) for insight into how it has been understood by various iwi. However, the chant's wairua, or its essence, evokes the Māori migration from Hawaiki. It contains several metaphors relating to firmness and stability, such as the sky above and the earth below, and the strength of the more, the tap root, and Hawaiki as a source of ritual power, strength and identity. Tumamao Harawira saw the chant as a good way "to set the stage" for his show; it was also short, taking up $20 \mathrm{~s}$ of a one-minute intro.

Fellow Manako host Eruera Lee-Morgan said it was important for broadcasters to be creative in their use of language, but he did not believe that imaginative reworking diminished "the stuff of our ancient past". In one opening, he used a core element of the chant above the phrase "whakatau hā" - to unify the elements that needed to be present: Acknowledgement of the primal parents; acknowledgements to the dead; greetings to the living; and an invitation to listeners to enter the figurative marae of Manako. He interpreted "whakatau hā" in this context as "welcome".

This was the mihi to Rangi and Papa:

Whakatau hā, whakatau hā, whakatau hā te rangi e tū iho nei, whakatau hā te papa e takoto nei. [Welcome, welcome, welcome the sky father, welcome the earth mother].

The next part paid homage to the dead, describing them in terms of Hine-nui-te-pō, the guardian of the dead: 
Whakatau hā ō tātou tini aituā ki a Hine-nui-te-pō. [Welcome our numerous deceased dwelling in the realm of Hine-nui-te-pō].

He then turned to the living, using the metaphor of Tāne, who created the world of light after pushing his parents apart:

Whakatau hā tātou ko te hunga ora ki a Tāne-te-waiora. [Welcome us, the living, in the realm of Tāne-te-waiora].

Listeners were greeted:

Whakatau hā koutou e ngā iwi o te motu ki te marae areare o Manako e whakatau nei i a koutou. [Welcome the tribes of the country to the marae of Manako hereby greeting you] (Manako, August 24, 2017).

This appealing reworking weaves links between the past and present, and between all of those linked at that moment by their shared listenership. It is also pithy: The words above took $18 \mathrm{~s}$ to deliver in a $1 \mathrm{~min} 06 \mathrm{~s}$ introduction. Lee-Morgan summed up his approach with the phrase, "He iti te kupu kia nui te kōrero", or "A short address expresses a great deal". Brevity and clarity, he said, were at the heart of the "art of oratory ... no matter what the platform is, on marae or on the airwaves".

\section{Conclusion}

Through textual, intertextual and conversation analysis, this novel paper has demonstrated how elements of the art of oratory have become part of news, both in the language of news stories and the elements that frame them. The impetus to refashion elements of whaikōrero arises from each reporter's cultural skillset and their sense of what is contextually appropriate, and it is clear that presenters and reporters feel trusted to make culturally congruent decisions. However, they are conscious of the need to balance both news and language 
revitalisation goals, and, within their creativity, aim to employ a vocabulary that is broadly understood. 


\section{References}

Anderson, A., Binney, J., \& Harris, A. (2014). Tangata whenua: An illustrated history. Bridget Williams Books.

Bainbridge, J. (2008). Textual analysis and media research. In J. Bainbridge, N. Goc, \& N. Tynan (Eds.), Media \& journalism: New approaches to theory and practice (pp. 224-237). Oxford University Press.

Barlow, C. (1991). Tikanga whakaaro: Key concepts in Māori culture. Oxford University Press.

Bazerman, C. (2004). Intertextuality: How texts rely on other texts. In C. Bazerman \& P. A. Prior (Eds.). What writing does and how it does it: An introduction to analyzing texts and textual practices (pp. 83-96). Lawrence Erlbaum Associates.

Brooke-White, V. (Ed.). (1981). Whaikoorero: Ceremonial farewells to the dead. Continuing Education Unit, Radio New Zealand.

Deverson, T., \& Kennedy, G. (Eds.). (2005). New Zealand Oxford dictionary.

Dewes, T. K. (1975). The case for oral arts. In M. King (Ed.). Te ao hurihuri the world moves on: Aspects of Maoritanga (pp. 46-63). Hicks Smith.

Durie, M. K. (2011). He kawa oranga: Mãori achievement in the 21st century [Doctoral thesis, Massey University]. https://mro.massey.ac.nz/handle/10179/3437

Durie, M. K. (2012). Tikanga in changing worlds. In A. Mikaere \& J. Hutchings (Eds). Kei tua o te pae: Changing worlds, changing tikanga - educating history and the future. (pp. 77-86). Te Wānanga o Raukawa \& New Zealand Council for Educational Research.

Fairclough, N. (1992). Discourse and social change. Polity Press.

Fairclough, N. (2003). Analysing discourse: Textual analysis for social research. Routledge.

Firth, R. (1926). Proverbs in native life, with special reference to those of the Maori, II. (continued). Folklore, 37(3), 245270 . 
Fürsich, E. (2009). In defense of textual analysis. Journalism Studies $10(2)$

https://doi.org/10.1080/14616700802374050

238-252.

Hannis, G. (2014). News writing. In Intro: A beginner's guide to journalism in 21st-century Aotearoa/New Zealand. New Zealand Journalists Training Organisation.

Haunui-Thompson, S. (2015, October 21). Māori TV hunts for new Auckland home. Radio New Zealand. https://www.rnz.co.nz/

Henshall, P., \& Ingram, D. (2012). The news manual [Educational https://www.thenewsmanual.net/index.htm

Hiroa, T. R. (1949). The coming of the Maori. Māori Purposes Fund Board, Wellington.

Karetu, T. (1992). Language and protocol of the marae. In M. King (Ed.), Te ao hurihuri: Aspects of Maoritanga (pp. 2841). Reed.

Kāretu, T. (2008). Te kete tuawhā, te kete aronui - the fourth basket.

$\mathrm{Te}$

Kaharoa,

$1(1)$. https://doi.org/10.24135/tekaharoa.v1i1.135

Liddicoat, A. (2011). An introduction to conversation analysis. Continuum.

Mahuta, R. T. (1974). Whaikoorero: A study of formal Māori speech. [MA thesis, University of Auckland]. University of Waikato Research Commons. https://hdl.handle.net/10289/11485

Marsden, M. (2003). The woven universe: Selected writings of Rev. Māori Marsden (T. A. C. Royal, Ed.). Estate of Rev. Māori Marsden.

McKee, A. (2003). Textual analysis: A beginner's guide. Sage Publications.

McRae, J. (2017). Māori oral tradition: He kōrero nō te ao tawhito. Auckland University Press.

Mead, H. (2003). Tikanga Māori: Living by Mãori values. Huia.

Mead, H., \& Grove, N. (2003). Ngā pēpeha a ngā tīpuna. Victoria University Press.

Metge, J., \& Jones, S. (1995). He taonga tuku iho nō ngā tūpuna: Māori proverbial sayings - a literary treasure. 
The Journal of New Zealand studies, 5(2), 3-7. https://ojs.victoria.ac.nz/jnzs/article/view/471

Middleton, A. (2020). Kia hiwa rā! The influence of tikanga and the language revitalisation agenda on the practices and perspectives of Māori journalists working in reo-Māori news [Doctoral thesis, Auckland University of Technology].

Tuwhera. https:/ / openrepository.aut.ac.nz/handle/10292/13286

Middleton, J. (2010). Ka rangona te reo: The development of Māori-language television broadcasting in Aotearoa New Zealand. Te Kaharoa, 3(1), 146-176. https://doi.org/ 10.24135/tekaharoa.v3i1.122

Moorfield, J. (n.d.). Te aka online Māori dictionary. https: / / maoridictionary.co.nz/

Moorfield, J., \& Johnston, L. (2004). Te reo Māori: Origins and development of the Māori language. In T. Ka'ai, J. Moorfield, M. Reilly, \& S. Mosley (Eds.), Ki te whaiao: An introduction to Māori culture and society (pp. 36-49). Pearson Education New Zealand.

Moyers, B. (1999, June). The mythology of 'Star Wars' with George Lucas. http: / billmoyers.com/content/ mythology-of-star-warsgeorge-lucas /

Orbell, M. (1985). The natural world of the Maori. Collins: David Bateman.

Orr, M. (2011). Intertextuality. In M. Ryan, G. Castle, R. Eaglestone, \& M. K. Booker (Eds.), The encyclopedia of literary and cultural theory (Vol. 2, pp. 641-645). Wiley.

Parker, B. (1966, March). Nga whakatauki: Maori proverbs and sayings. Te Ao Hou The Maori magazine, 54. http://teaohou.natlib.govt.nz/journals/teaohou/issue/ Mao54TeA/c4.html

Reed, A. W., \& Calman, R. (2004). Reed book of Māori mythology. Reed.

Rerekura, S. (2007). Whaikōrero: Tauparapara 1. Sam Rerekura.

Rerekura, S. (2008). Whaikōrero hunga mate 1: A study of the 'sacred references to the dead' and formal conclusions in 
indigenous oral literature. Te Whare Wānanga o Ngāpuhinui-tonu.

Rewi, P. (2004). Ko te waihanga me ngā wehewehenga o te whaikōrero: The structural system of whaikōrero and its components. Junctures, 2(2004), 17-32. https://junctures.org/index.php/junctures/article/vie $\underline{w} / 148 / 151$

Rewi, P. (2010). Whaikōrero: The world of Māori oratory. Auckland University Press.

Richardson, J. (2007). Analysing newspapers: An approach from critical discourse analysis. Palgrave Macmillan.

Salmond, A. (2004). Hui A study of Māori ceremonial gatherings ( $3^{\text {rd }}$ ed.). Penguin Group.

Shirres, M. P. (1997). Te tangata: The human person. Accent Publications.

Sidnell, J. (2011). Conversation analysis: An introduction. Wiley-Blackwell.

Smith, A., \& Higgins, M. (2013). The language of journalism: A multi-genre perspective. Bloomsbury Academic.

Statistics New Zealand. (2014a). Te Kupenga. http://www.stats.govt.nz/browse_for_stats/people_and_ communities/maori/TeKupenga_HOTP13.aspx

Statistics New Zealand. (2014b). Measuring te reo Māori speakers: A guide to different data sources. http://archive.stats.govt.nz/browse_for_stats/people_a nd_communities/maori/measuring-te-reo-maorispeakers.aspx\#gsc.tab $=0$

Taonui, R. (2006). Ranginui the sky. Te ara the encyclopedia of New Zealand. http://www.TeAra.govt.nz/en/ranginuithe-sky/page-2

Te Māngai Pāho. (n.d.). Why we are here. [Web page]. https://www.tmp.govt.nz/why-we-are-here

Walker, R. (1978). The relevance of Māori myth and tradition. In Tihe mauri ora: Aspects of Maoritanga (pp. 19-32). Methuen.

Walker, R. (2004). Ka whawhai tonu mātou: Struggle without end. Penguin.

Walker, W. (2014). Ngā maunga kōrero o te Tairāwhiti. https://maungakorero.wordpress.com/maunga-korero/ 
Walter, R., \& Reilly, M. (2018). Ngā hekenga waka: Migration and early settlement. In L. Carter, S. Duncan, G. Leoni, L. Paterson, M. Ratima, M. Reilly, \& P. Rewi (Eds.), Te Kopparapara: An introduction to the Mãori world (pp. 6786). Auckland University Press.

Williams, H. W. (1971). A dictionary of the Mãori language (7th ed.). Legislation Direct. 